NBER WORKING PAPER SERIES

\title{
THE EFFECTS OF MULTISPECIALTY GROUP PRACTICE ON HEALTH CARE SPENDING AND USE
}

\author{
Laurence C. Baker \\ M. Kate Bundorf \\ Anne Beeson Royalty \\ Working Paper 25915 \\ http://www.nber.org/papers/w25915 \\ NATIONAL BUREAU OF ECONOMIC RESEARCH \\ 1050 Massachusetts Avenue \\ Cambridge, MA 02138 \\ June 2019
}

Thanks to the National Institute for Health Care Management for research support and to Ausmita Ghosh and Jason Tilipman for research assistance. Royalty acknowledges IUPUI for supporting this research through a sabbatical research leave. Baker and Bundorf acknowledge research support from AHRQ RO1 HS024535. The views expressed herein are those of the authors and do not necessarily reflect the views of the National Bureau of Economic Research.

At least one co-author has disclosed a financial relationship of potential relevance for this research. Further information is available online at http://www.nber.org/papers/w25915.ack

NBER working papers are circulated for discussion and comment purposes. They have not been peer-reviewed or been subject to the review by the NBER Board of Directors that accompanies official NBER publications.

(C) 2019 by Laurence C. Baker, M. Kate Bundorf, and Anne Beeson Royalty. All rights reserved. Short sections of text, not to exceed two paragraphs, may be quoted without explicit permission provided that full credit, including $(\odot$ notice, is given to the source. 
The Effects of Multispecialty Group Practice on Health Care Spending and Use Laurence C. Baker, M. Kate Bundorf, and Anne Beeson Royalty

NBER Working Paper No. 25915

June 2019

JEL No. I11

\begin{abstract} how a primary care physician's practice type - single (SSP) versus multispecialty practice (MSP) - affects health care spending and use. Focusing on Medicare beneficiaries who change their primary care physician due to a geographic move, we compare changes in practice patterns before and after the move between patients who switch practice types and those who do not. We use instrumental variables to address potential selection by patients into practice types after the move. We find that changing from a single to a multi-specialty primary care group practice decreases annual Medicare-financed per capita expenditures by about $\$ 1,600$ - a 28\% reduction. The effect is driven primarily by changes in hospital expenditures and is concentrated among patients with two or more chronic conditions, suggesting that MSP improves care delivery by reducing hospitalizations among relatively sick patients. The results imply that, while research has shown the potential for physician consolidation to increase prices in some settings, large multispecialty groups also have the potential to lower costs.

Laurence C. Baker

Department of Health Research \& Policy

HRP Redwood Bldg, Rm T110

Stanford University

Stanford, CA 94305-5405

and NBER

laurence.baker@stanford.edu

M. Kate Bundorf

Health Research and Policy

Stanford University

HRP T108

Stanford, CA 94305-5405

and NBER

bundorf@stanford.edu

Anne Beeson Royalty

IUPUI

Department of Economics

Cavanaugh Hall (CA) 509D

425 University Boulevard

Indianapolis, IN 46202

royaltya-dua50786@nber.org
\end{abstract}

U.S. physicians are increasingly joining multispecialty group practices. In this paper, we analyze 
Physician practices in the U.S. have been increasing in size and scope. In 1998, 29\% of physicians worked in solo practices and only 13\% worked in practices of 100 or more. By 2010, this was nearly reversed with $24 \%$ of physicians in practices of 100 or more and only $18 \%$ in solo practices (Baker et al., 2018). As the vast majority of very large practices are multispecialty (MSP) rather than single specialty (SSP), this growth in practice size has been accompanied by a shift toward MSP. Despite this transition, many physicians continue to work in small practices - in 2010, $40 \%$ of physicians worked either in solo practice or in a group with 2 to 9 physicians (Baker et al., 2018). Continued interest among public and private payers in moving away from volume-based payment using "alternative payment models" is likely to continue the trend toward larger, more integrated physician organizations.

While the pervasive view underlying many of these policies is that larger, more integrated organizations provide care more efficiently primarily through greater coordination of care (Baicker and Levy, 2013), the literature on physician integration largely does not support this view (Burns, Goldsmith et al. 2013). In a comprehensive review of the literature from the 1970s to the present, Burns et al. (2013) find little evidence that these arrangements systematically improve quality or lower costs. They note, however, several gaps in the literature making it difficult to draw conclusions from the studies they reviewed. The studies cover a very long time-period during which the health care market changed in many ways, including the rise of managed care plans and dramatic developments in the capabilities and use of information technology. In addition, much of the evidence is based on case studies of one or a few organizations, and study outcomes are often very basic and, in many cases, self-reported. A recent study documenting that larger practices are characterized by higher rates of preventable admissions and higher overall spending than their smaller counterparts also challenges the conventional wisdom larger physicians organization are able 
to reduce health care expenditures through more effective care coordination (Casalino et al., 2018, 2014).

Against this relatively sparse evidence supporting the beneficial effects of larger, more integrated provider organizations is a growing body of literature documenting that physician consolidation increases prices for health care services (Baker et al., 2014b; Dunn and Shapiro, 2014). While the policy objective of promoting larger organizations is that it may lead to more coordinated care, the potential downside is that it may generate market power on the part of providers leading to higher prices for health care services (Baicker and Levy, 2013). Evidence of higher prices, however, does not necessarily signal that integrated groups are not providing health care more efficiently. Firms may have different motives for integrating; they may integrate explicitly to achieve market power or they may integrate with the objective of providing care more efficiently, with the generation of market power as a by-product (Bresnahan and Levin 2012). Thus, evidence of a positive relationship between provider market concentration and prices leaves open the possibility that integration could, on net, have beneficial effects on the efficiency of health care delivery. However, better evidence of the effects of integration on care delivery is essential for evaluating the implications of these types of organizational changes for consumers and patients.

In this paper, we analyze how physician practice type - single specialty (SSP) versus multispecialty practice (MSP) - affects the cost and use of care for U.S. Medicare beneficiaries. We focus on the organization of primary care practice, as a patient's primary care physician often serves as a patient's agent in navigating the health care system (Fuchs, 1998). Our basic approach is to use a difference-in-difference design to examine spending and outcomes for patients who move across geographic areas, comparing those who remain in the same types of practice (SSP versus MSP) to those who change practice types. By focusing on movers, we observe a set of patients who are 
required to change the set of providers from whom they receive care for reasons arguably independent of their health status (Finkelstein et al., 2016). While the decision to move may be exogenous with respect to health status, the choice of practice type in the destination location may not be - patient preferences for health care delivery may be correlated with both their health status and their choice of practice type. To address demand-side selection, we use instrumental variables to generate exogenous variation in the organization of the practice of the patient's post-move primary care physician. The instrument is the market-level organization of primary care practice in the geographic area to which the patient moved. Our instruments require, however, that market-level practice-type share affects expenditures only through its effect on patient decisions regarding the practice type of their primary care physician. Supply-side changes in health care delivery, such as changes in the organization of insurer markets or hospital-physician integration, may affect marketlevel health care delivery in ways that would create an alternative channel through which patient choices may be correlated with health care spending and use, violating the assumptions necessary for the instrument to generate unbiased estimates. Our movers approach offers an important advantage in addressing this concern. In particular, it allows us to include HHR-by-year fixed effects, enabling us to control for both fixed and time varying characteristics of markets that may affect both practice type share and spending outcomes.

We find the MSP decreases Medicare-financed per capita annual medical expenditures by approximately $\$ 1,600$ relative to SSP - a 36\% reduction. The reduction is concentrated primarily on hospital spending and on patients with two or more chronic conditions. Taken together, these results suggest that MSP is more effective at keeping relatively sick patients out of the hospital. Our results also suggest that multispecialty group practice attracts less healthy patients, and our research design provides some insight into the source of unfavorable selection into MSPs. While the OLS results indicate that MSPs are more costly, when we instrument actual practice type switch with 
share of practice type in the destination HRR, we find that that MSPs have significantly lower costs per patient than SSPs. Because our difference-in-difference analysis without instruments controls for unobservable differences in patients that are fixed over time, the deviation between the OLS and IV results indicates that patients select MSP after the move based on changes in their unobserved health status around the time of the move.

We improve on existing work by providing one of the first analyses of the effects of physician organization that is national in scope and is based on administrative data to measure outcomes; the bulk of the literature is based on case studies of a single or a few organizations and often relies on self-reported data (Burns et al., 2013). While more recent studies have begun to analyze broader sets of organizations using administrative data (Casalino et al., 2018, 2014; Weeks et al., 2010), they have not directly addressed the complex selection issues potentially affecting this literature. For example, Weeks et al. (2010) compare patients receiving care from large multispecialty practices associated with the Council of Accountable Physician Practices (CAPP) with patients receiving care from other physicians in the same market - a mix of physicians who are part of other multispecialty or single specialty groups or who are unaffiliated. They find that patients in CAPPaffiliated practices - all large MSPs -- had slightly lower costs (3.6\%) and higher quality. CAPP affiliated practices, however, represents only a subset of physicians in the market. As a result, the findings are unlikely to represent a generalizable effect of MSP on care delivery potentially due to selection of physician groups into CAPP affiliation, the presence of many patients with primary care physicians in MSPs in the control group, and the selection of patients into MSP. Our results are similar to those from a recent study examining primary care physician consolidation which uses physician relocation to identify the effects of practice organization on health care use (Chen et al., 2019). 
Our results provide new evidence for consideration in the development of antitrust policy with respect to multispecialty group practice by demonstrating that patients receiving care from primary care physicians associated with multispecialty practices use substantively less care than their counterparts seeking care from primary care physicians who are not part of multispecialty practice. While evidence on the effects of MSP on health care quality and outcomes is necessary to fully evaluate the implications of our findings, any negative effects of the formation of larger multispecialty groups in the form of higher prices due to greater market power should be weighed against any increases in efficiency leading to lower costs.

\section{Theoretical Framework}

Our theoretical framework focuses on how integration between primary care physicians and specialists affects health care delivery. In a MSP, physicians of different specialties work together as part of a single organization. In a SSP, primary care physicians coordinate treatment decisions with other independent physicians or group practices. The economics literature offers several mechanisms by which integration between primary care physicians and specialists could increase the efficiency of health care delivery.

Models based on contract theory emphasize the existence of externalities in production when separate organizations are involved in joint production. Under these conditions, integration can lead to higher profits if the integrated organization can internalize the externality (Hart and Holmstrom, 2010). These theories propose that larger and more integrated organizations may produce more efficiently when ambiguity exists in the specific tasks necessary for production, when specific assets are necessary for production, or when difficulty measuring and verifying outcomes makes it difficult to write contracts that adequately specify the set of possible contingencies relevant for production (Bresnahan and Levin, 2012). Because each of these characteristics is inherent to the 
production of health care, integrated organizations, in this case, MSP, may be a mechanism for overcoming problems of incomplete contracts that hinder coordination among non-integrated providers.

(Rebitzer and Votruba, 2014), hower, argue that the economic theory on the mechanisms by which integrated organizations may improve care is not well developed. The clinical literature points to the potential for integration to facilitate consultation among physicians of different specialties for patients with complex conditions that are difficult to diagnose and manage:

"Somebody comes in with a very difficult problem and gets taken care of by the internist and the surgeon and the radiologist and anesthesiologist, all of whom know each other, work together, eat lunch together," said Dr. Maurice Fox, a retired [Palo Alto Medical] Clinic endocrinologist. ${ }^{1}$

A formal literature points to multispecialty groups as an organizational response to the "referral problem", a situation which requires an agent responsible for diagnosing a patient to either treat the patient or refer the patient to a specialist (Garicana and Santos, 2010). Spot contracts, the types of payment systems generally used in the absence of integration, create incentives for underreferral - less skilled agents hold on to opportunities for which more skilled agents have a comparative advantage. Groups, in contrast, through income-sharing arrangements, can create incentives for efficient referral. Consistent with more efficient referral patterns, Epstein, Ketcham et al. (2010) demonstrate that greater specialization, in the form of physicians who focus on highrisk deliveries, exists among obstetricians working in groups than among those working individually,

\footnotetext{
${ }^{1}$ http://www.pamf.org/about/pamfhistory/grouppractice.html accessed November 12, 2016.
} 
and that greater specialization leads to better matching of patients to physicians and improved health outcomes.

Group practice, whether single or multispecialty, may also generate economies of scale or scope. Since many of the costs of monitoring new evidence and implementing appropriate changes in response have components that are fixed across multiple doctors, economies of scale likely exist in accessing and internalizing evidence about new medical treatments and technologies. In a study gathering qualitative evidence on group formation, some physicians expressed the view that groups need to be at least moderately sized "to create organized processes that will improve care" (Casalino et al., 2003). The high fixed costs of information technology, such as the implementation of electronic medical records, is another potential source economies of scale (Gans et al., 2005). While these examples are driven in part by group size and, thus, are not restricted to multispecialty, as opposed to single specialty group practice, multispecialty group practices are often larger and able to spread very high fixed cost investments over an even larger number of physicians or may be able to take advantage of complementarities across specialties in improving processes of care. Previous work has reported apparent economies of scale in physician practice size (e.g. (Bradford and Martin, 2000), although has not identified the specific source of these differences.

While these theories point to the potential for efficiencies associated with mulitspecialty group practice, thre are also reasons why these efficiencies may not materialize. First, large physician groups have greater difficulty translating group incentives to the behavior of individual practitioners and weaker individual-level incentives may lead to less effort (Gaynor et al., 2004; Gaynor and Gertler, 1995), making it difficult to achieve any potential increases in efficiency. Relatedly, qualitative interviews point to a lack of a tradition of organizational leadership roles among physicians and, correspondingly, a lack of compensation systems that reward physicians for organizational leadership (Casalino et al., 2003). Physicians also often cite a desire for autonomy and 
difficulty in cooperating with each other as barriers to forming groups (Casalino et al., 2003). These factors may hinder the ability of larger multispecialty groups to drive the types of substantive changes in care delivery that may be necessary to achieve the gains from greater coordination. The existence of these types of costs suggests that multispecialty groups will form when the benefits in the form of greater profitability due to coordinated production are relatively large. They also help to explain the observed heterogeneity in the decisions of small groups or individuals to form multispecialty organizations since these costs are likely to vary across individuals and small groups. Finally, economies of scale and scope may be limited. A comprehensive review found limited evidence on the existence of scope economies and suggested that any scale economies appeared to be reached by a group size of about 10 - far smaller than most of the multispecialty group practices observed in the market (Burns et al., 2013).

The impact of larger, more integrated organizations on health care delivery also likely depends on the financial incentives facing organizations. When delivery organizations receive feefor-service payment, they have incentives to provide more services and more profitable services. Under payment schemes, such as capitation, in which they bear the financial risk associated with greater utilization, in contrast, using fewer services and fewer costly services increases profitability. Thus, how organizations are paid may determine how they use any advantages related to coordination or economies of scale to increase profitability. For example, larger groups may be able to respond more effectively to FFS incentives by investing in and using ancillary services that support large profit margins (Casalino et al., 2003), effectively increasing total cost of care. In contrast, groups paid by capitation or other risk-bearing payment forms would have incentives to use these types of services more parsimoniously, effectively lowering cost of care. Thus, the extent to which and how organizations use greater coordination among physicians to increase profits depends on the financial incentives facing the organization. 
In this paper, we study traditional Medicare, a setting in which physicians are paid largely by fee-for-service, suggesting that greater coordination will lead to greater use of more and more profitable services that are billed by the organization. Yet, many physicians serve patients enrolled in Medicare Advantage plans as well as traditional Medicare, and there is evidence that practice styles developed in response to incentives created by both Medicare Advantage enrollees and Accountable Care Organizations spill over into outcomes for patients in the practice whose costs are not reimbursed under these organizations (Baker, 1997; Chernew et al., 2008; McWilliams et al., 2013). This suggests that it is costly to distinguish between patients within a practice covered by different types of insurance and that therefore, FFS financial incentives may be blunted in settings where physicians are treating both managed care and FFS patients.

Finally, research in industrial organization also emphasizes strategic rather than efficiency motivations for vertical integration - integration can be a tool for consolidating or extending market power (Whinston, 2007). In other words, firms may not integrate with the objective of increasing health care efficiency, but rather for charging higher prices or influencing referral patterns. While there is little evidence on the competitive effects of multispecialty groups, research from physician and hospital markets suggest that these types of motivations for integration are important. Larger physician groups charge higher prices (Baker et al., 2014b; Dunn and Shapiro, 2014) and vertical integration between hospitals and physicians also leads to higher prices for hospital services (Baker et al., 2014a). In a review of the literature on physician organization, Burns and coauthors conclude that the scale and scope economies of physician practice are limited and suggest that market power is a primary motivation (Burns et al., 2013). Thus, integration may not necessarily lead to greater efficiency in the production of services if the primary motivation for integration is to increase market power. Our analyses of claims of Medicare patients will, however, pick up only utilization differences, not price differences, since Medicare operates under administered prices. 
In summary, our theoretical framework suggests that, while MSP may allow physicians to provide services more profitably through greater care coordination across physicians, the implications for expenditures, particularly for physician services are not straightforward. In particular, fee-for-service payment may create incentives for physicians to leverage greater coordination to provide more services, particularly those that are both beneficial for patients and generate payments for physicians. To the extent that larger MSPs are more likely to have riskbearing payment contracts for at least of subset of their patients, however, may dampen these incentives by making greater utilization less profitable for at least a subset of patients. In the end, the effects of MSP on health care delivery is an empirical question.

$\underline{\text { Data }}$

We use data from Medicare claims for 1999-2010. Our data contain information about all Medicare-billed services provided to a 20\% random sample of traditional (fee-for-service) Medicare beneficiaries during this time period. We use claims from physician offices, hospital outpatient departments and inpatient hospitalizations.

Study Sample

As described in more detail below, most of our analyses use only a sample of geographic movers. Beneficiaries are classified as geographic movers if their hospital referral region (HRR) of residence changes during the financial year (between April $1^{\text {st }}$ of year $\mathrm{t}$ and March $31^{\text {st }}$ of year $\mathrm{t}+1$ ) as defined by IRS records. We develop our sample following the sample restrictions of (Finkelstein et al., 2016). We retain individuals over age 65 and under age 99, and those with both Medicare Part A and Part B coverage but who are not enrolled in Medicare Advantage for each month in the data. Those beneficiaries with more than one move are excluded to provide cleaner "before" and "after" move periods. Also following Finkelstein et al. (2016), for movers, we compare the share of claims 
in the destination HRR before and after the move, and drop those patient-years where the difference is less than 0.75. This restriction is meant to exclude those who divide time between two residences and those who do not physically move to a new location but have some reason to change their IRS address. For comparison purposes, we also retain a 25\% random sample (of the $20 \%$ Medicare sample) of non-movers. Non-movers are defined as those observed always residing in the same HRR.

$\underline{\text { Measures }}$

Identifying Physician Practice Type

We use Medicare claims to characterize physician practice types. The Medicare claims data include the physician's unique identifier, tax ID number of the practice that the physician is affiliated with, and the physician's specialty. Following previous work (Baker et al., 2018, 2014b), we identify physicians reporting the same tax ID numbers on their claims as part of the same practice. In this study, we restrict our analysis to practices with at least one primary care physician, where primary care physicians, as defined by CMS, are those reporting specialties of general practice, family practice, geriatrics and internal medicine. We use the information on physician specialty and the tax ID-based practice definition to classify practices into two groups: (1) single specialty primary care practices (SSPs) and (2) multispecialty practices (MSPs). SSPs include both solo and group primary care practices. For this study, multispecialty groups must include at least one primary care physician (since we assign patients to practices based on where the patient receives most of his primary care) and at least one physician specializing in something other than primary care. ${ }^{2}$

\footnotetext{
2 Physicians can have multiple specialties listed in the data and we use only that specialty of the physician that accounts for the maximum number of claims. Physicians with specialties identified as pediatrics, multispecialty group, osteorelated, other surgery unmatched, and other unmatched specialties were removed from the sample.
} 
Claims for all beneficiaries in the 20\% Medicare sample are used to categorize practice types and to construct a measure of the total number of physicians in each practice. In prior work, we concluded that the $20 \%$ sample will include the vast majority of physicians providing services to Medicare patients (Baker et al., 2018). For example, we found 566,149 unique physician ID's in the 2010 data. This is consistent with other calculations that, though done in a slightly different way, reported the number of physicians appearing in the 2010 100\% sample of Medicare claims (Welch, Cuellar et al. 2013). ${ }^{3}$

We follow the Accountable Care Organization (ACO) assignment strategy to assign patients to primary care physicians and thereby practice type (CMS, 2014). Patients must be assigned to a physician in order to track an ACO's performance and CMS provides rules for that assignment when patients see physicians in multiple practices. In our setting this assignment strategy simply requires that a patient's home practice is the practice in which she has the maximum charges by a primary care physician in a particular year. For geographic movers, we assign the beneficiary to a practice in both the year before and the year after a geographic move. Because we know only the year of the move and not the exact date, we exclude the year of the move from the analysis and only examine outcomes in the year before and the year after the move.

\section{Dependent V ariables}

Key outcome variables include expenditures incurred for physician services, outpatient visits and inpatient visits. We construct these variables by summing expenditures from claims files within the year before the move and within the year after the move. Expenditures include those from the

\footnotetext{
3 As a further way of gaining information about the completeness of the $20 \%$ sample data, we computed the number of unique physician IDs in the $20105 \%$ sample of Medicare claims. We found $94 \%$ of the total in the $20 \%$ sample were also found in the $5 \%$ sample. Because nearly all of the physicians identified in the $20 \%$ sample are also identified with only the $5 \%$ sample, we take it as unlikely that there would be a large number of additional physicians providing services to Medicare patients that are not represented in the $20 \%$ sample.
} 
practice assigned as the patient's home practice as well as those from practices other than the patient's home practice. Total expenditure measures include expenditures on physician and other provider visits, outpatient visits, and hospitalizations, including both Medicare- and beneficiaryfinanced components of expenditures. We also estimate separate models by expenditures type (physician, hospital and outpatient) and examine measures of health care use including indicators of whether the patient was hospitalized one or more time or 2 or more times in a given year.

\section{Control Variables}

The claims data provide information on demographics and health status. Demographic variables include age, sex, and race (white or non-white). We also control for the presence of chronic conditions including diabetes, heart disease, kidney disease, heart failure, atrial fibrillation, COPD, asthma, arthritis, hypertension, and high cholesterol, as reported in the CMS Chronic Condition Warehouse data. In most of our analyses, we restrict the sample to one year before and after the move.

\section{Methods and Models}

Our basic specification is a difference-in-difference model comparing, among Medicare beneficiaries who experience a geographic move, those who do and do not switch practice type after their move. Restricting our analysis to Medicare beneficiaries who move allows us to focus on a set of patients who must change primary care physicians for reasons other than their health status. A naïve model of the effect of practice type on outcomes using patients that switch to a different practice type in the absence of a move, in contrast, faces the problem of whether people who change practice types- say, those moving to a MSP from a SSP_-differ from those who did not move in unobservable ways. Using a sample of geographic movers mitigates this selection problem because geographic movers must change their physician practice while those who do not move but 
change practices may be exceptionally motivated - perhaps by unobservable aspects of their health to change practices and practice types.

Focusing on our sample of geographic movers, we limit the dataset to one observation for the year before the move (pre-period) and one observation for the year after the move (post-period), for each person and estimate the following model on two mutually exclusive samples of movers: (1) beneficiaries receiving care in a single specialty practice before the move and (2) beneficiaries receiving care in a multispecialty practice before the move.

$$
Y_{\text {ipat }}=\beta_{0}+\beta_{1} \text { Switch }_{i}+\beta_{2} \text { Post }_{p}+\beta_{3} \text { Switch }_{i} * \text { Post }_{p}+X_{\text {iapt }} \gamma+\alpha_{a} * \tau_{t}+\varepsilon_{\text {ipat }} \text { (1) }
$$

Where i represents an individual, $\mathrm{p}$ represents whether the observation is the year pre- or post-move, a represents the geographic area as defined by HRR in the calendar year, and $\mathrm{t}$ represents calendar year.

"Switch" turns on in both periods if the person switches practice type after the move, "Post" indicates that the observation represents the year subsequent to the move, and "Switch*Post", the interaction of the two, represents the difference-in-difference estimate of the effect of changing practice type. We control for the time-varying characteristics of individuals as described above with $X_{\text {ipat }}$.

The model includes HRR*Year fixed effects, allowing us to control for both fixed and timevarying characteristics of markets. We can include HRR*Year fixed effects because the treatment, changing practice type, is not perfectly correlated with either area or calendar year. Because we are focusing on a sample of movers, each person in the dataset is observed in two geographic areas, an 
"origin" and a "destination" HRR, and we observe some people moving to and others moving away from each HRR.

Instruments

While limiting the sample to geographic movers mitigates selection driven by the types of patients who chose to change practices, movers must choose a new primary care physician practice after their move, creating the possibility of selection bias based on the types practices patients choose after the move. Additionally, because we do not observe the exact date of the move, we do not include data from the year of the move in our analysis. Thus, our estimates could also be biased if changes in health that occur around the time of the move - in this case an entire year - are correlated with choice of practice type in the new location.

To address potential bias due to demand-side selection of provider type after the move, we combine our difference-in-difference framework with an instrumental variables approach. Our instruments are based on the observation that people moving from the same HRR of origin may move to destination HRRs with differing distributions of practice types. We expect that the prevalence of different types of practices in the destination HRR does affect patients' choice of practice type but does not affect an individual patient's expenditures or outcomes through mechanisms other than practice type choice, conditional on including HRR*Year fixed effects in the model to control for any changes in the local market.

Specifically, our instrument, $Z_{\text {iat }}$ is the practice type share in the patient's post-move HRR. Z varies across, but not over time within individuals. The share of patients in each practice type in the HRR is calculated using the $20 \%$ sample of Medicare beneficiaries, and is not restricted to our sample of movers. In models of patients initially in SSPs and for whom a switch represents a switch to MSP, we instrument "Switch" with the share of patients in MSPs in the destination HRR in the year after the move. For those initially in a MSP, we instrument "Switch" with the share of single 
specialty practices in the destination HRR in the year after the move. We then use those instruments interacted with the Post dummy as instruments for (Switch to MSP)* Post and (Switch to Single Spec)*Post.

The identifying assumption is that the practice type share affects expenditures and other outcomes only through its effect on the decision to switch practice types, conditional on the other variables in the model. But there are potentially important market factors that are not fixed over time that could be correlated with the prevalence of MSPs or SSPs in the market. For example, perhaps markets with an increasing prevalence of MSPs are also markets in which either insurer concentration or physician-hospital integration are increasing. If these other time-varying marketlevel changes affect expenditures and are correlated with the change over time in practice type prevalence, then our instruments would be invalid.

We address this concern by including HRR-by-year fixed effects in the model. Although our instrument, practice-type share, varies by HRR-year, we are able to include HRR-by-year fixed effects without introducing perfect collinearity because of the way we have structured the data and how we define our instruments. The instrument is based on physician practice organization in the patient's destination HRR. However, we use the patient's destination share to instrument for switch in both the origin and destination observations for each patient. This introduces variation in the instrument within each HRR-Year, breaking the perfect collinearity that would occur if the instrument was constant within HRR*Year (as would be the case if the instrument were practice type share in the HRR of residence in the current rather than the destination year). This in turn allows us to include HRR-by-year fixed effects in the IV model. This is potentially very important since otherwise it would likely be impossible to control for all the market and other geographic factors that vary over time within HRRs and could be correlated with the share of practice types in an HRR and with patient treatment patterns. 
In the discussion above, we have identified several sources of threats to identification. When presenting the results, we compare estimates from models with only HRR and year fixed effects with those from models with HRR-by-year fixed effects as well as estimates from models with and without instruments to determine the sensitivity of our results to alternative empirical strategies. We also present information on how movement of patients both in and out of HRRs allows us to use an HRR-year-level instrument while also including HRR by year fixed effects in the models.

$\underline{\text { Results }}$

We identified 119,272 movers, as defined above, during the study period. Table 1 presents characteristics of movers and a 25\% random sample of people who remained in the same HRR during the study period. We find that movers are slightly older and more likely to be female and white. Movers, based on residence prior to the move, were more likely to be located in the south and the west than non-movers. Movers are slightly healthier than non-movers based on the average number of chronic conditions (2.00 for non-movers and 1.86 for movers), and movers are either equally or slightly less likely to have each of the conditions we examined.

A substantial number of people change practice type after a move. In Table 2a, which provides comparisons of the characteristics of patients based on their practice type before and after the move, we report the number of people in each group. Out of 119,272 geographic movers, 60\% (40\% plus 20\%) and 40\% (24\% plus 16\%) had primary care physicians in SSPs and MSPs, respectively, prior to the move. 36\% switched practice type after the move with $20 \%$ moving from SSP to MSP and 16\% moving the opposite direction.

The groups differ very little in their demographic characteristics including age, sex and race (Table 2a). Patients initially with MSP primary care physicians are disproportionately located in the Midwest. There is little difference in the pre-move health status of patients in the different groups. 
Table $2 \mathrm{~b}$ provides some information on the size and structure of the two types of groups SSPs and MSPs. SSPs tend to be very small groups. Average physician group size is 5 to 6 members for patients seeing SSP primary care physicians. For patients seeing MSP physicians, in contrast, average group size is 80 to 100 physicians, representing an average of 6 to 7 specialties.

\section{Effects of Practice Type on Total Spending}

Table 3 presents the estimates for the key variables of interest: the type of move variables interacted with Post, which capture the effect of each type of move, after the move, relative to patients who were cared for in the same type of practice both before and after the move. The OLS results indicate that moving to a MSP from a SSP is associated with a statistically significant and large $(\$ 1,085)$ increase in total expenditures, while there is a small, positive but not statistically significant effect for beneficiaries moving the opposite direction Table 3 -Columns 1 and 2).

In Columns 3 and 4, we include HRR-by-year rather than HRR and year fixed effects to control for time-varying characteristics of markets that may be correlated with both patient choice of provider and health care use. We find little evidence, however, of bias from these types of factors. The estimates in models 3 and 4 from models including HRR by year fixed effects are very similar to those in columns 1 and 2 which include HRR and year fixed effects.

In columns 5-8 of Table 3, we present estimates from the instrumented versions of Models 1-4. The instrumented models address the possibility of bias generated by a correlation between unobserved patient characteristics that influence demand for medical care and practice type choice in the destination HRR. Due to the difference-in-difference design, the instrumented estimates address changes in patient health status. As discussed earlier, we instrument the switch indicator with practice type share in the destination HRR. The results indicate that this is an important source of bias. While the OLS results show an association between higher costs and being treated in a MSP 
practice (Table 3 - Column 1), the evidence from the IV models shows the opposite. In the IV specifications, moving to a MSP practice (Table 3 - Column 5) lowers expenditures by approximately $\$ 1600$, while the opposite direction move from a MSP to a single specialty practice (Table 3 - Column 6) increases expenditures by almost exactly the same amount. In summary, using instruments to control for endogeneity in patient choice of practice type reverses the direction of the estimate of the effect of changing from a SSP to a MSP and introduces symmetry in the estimates of switching from one direction to the other.

In columns 7 and 8 of Table 3, we reestimate the instrumented models, including HRR by year, rather than HRR and year, fixed effects. We find that the estimates are very similar to the instrumented estimates in columns 5 and 6 . This is consistent with the results in columns 1 through 4, which indicate that within-market changes in supply-side characteristics are not an important source of bias in our analyses.

\section{Identifying Variation}

As discussed earlier, while we focus on movers to generate arguably exogenous sources of changes in practice type, our differences-in-differences strategy faces potential bias from both demand and supply side sources. From the demand side, patient decisions regarding practice type, conditional on moving, may be correlated with difficult-to-observe changes in their health status. For example, among those who move, people with worsening chronic conditions may be more likely to choose a multi-specialty practice in their new location. From the supply side, changing market characteristics, such as increasing insurer concentration, may be correlated with both changes in practice types and patient expenditures. Because we focus on movers, the structure of our data allows us to address both sources of bias. We instrument patient switching with the share of 
practices of a particular type in the destination HRR to address patient selection into practice type, and we include HRR by year fixed effects to control for changing market characteristics.

We are able to adopt both strategies simultaneously because our instrument is not perfectly correlated with the HRR by year fixed effects. More specifically, the identifying variation is of two types. First, there is variation due to the fact that two individuals may move from the same HRR in the same year to different destination HRRs; therefore the instruments based on the practice share in the destination HRR vary within the Origin $\mathrm{HRR}^{*}$ year combination. Second, identifying variation occurs when, in a given HRR and year, we observe one beneficiary moving into that HRR and another mover moving out. This creates variation within the HRR*year since the practice share instrument for movers who moved into that HRR is based on the practice share of the current HRR, while the instrument for movers who move out of that HRR is based on the practice share in their new location. Importantly, in this case there is also variation within the HRR*Year in the share*post instrument because some movers in the HRR*Year are in the pre-period and others are in the post-period. In short, our ability to control for both demand -and supply-side sources of bias is based on the fact that we observe market conditions (by controlling for HRR*Year) for patients both leaving and arriving in a given HRR in a given year, allowing us to control for time-varying market characteristics. The variable we are instrumenting for, in contrast, is a person-level characteristic (whether the person switched practice type after the move) which is held constant in both periods in which we observe an individual even though their geography is changing.

Identification is, thus, dependent upon observing many different HRRs as both origin and destination locations for patients. In Table 4, we present evidence on the extent to which this type of variation exists in the dataset. We observe an average of 65 people in each HRR-year. HRRyears are usually observed as both destination and origin locations. In a given HRR, on average, forty-six percent of these observations are as on origin HRR and 54\% are as a destination HRR. 
For a given HRR in a given year, patients come from and move to many different locations. When an HRR-year is observed as an origin, it has on average 38 different destination. When an HRR-year is observed as a destination, patient come from an average of 52 different origins.

Appendix Table 1 presents the first stage results for the IV model. The instruments are highly predictive and easily pass the weak instruments test.

Interpreting the Differences between the OLS and IV Estimates

Figures 1 and 2 provide a graphical representation of the difference between the OLS and IV results. In all cases, health expenditures increase after the move. (Note that the estimates in the figure are not adjusted and part of the increase represents the aging of the sample over the study period). Focusing on observed switching from SSP to MSP (Figure 1 - Top Panel), the increase in expenditures associated with the change to MSP is driven by the relatively large increase in expenditures among patients who change to MSP - an increase of $\$ 4,514$ to $\$ 7,986$. The corresponding change among patients who do not change practice type - they remain in an SSP - is an increase of $\$ 4,402$ to $\$ 6,749$. Thus, the positive OLS estimate of the effect of MSP is driven by the larger increase in expenditures among those who actually enroll in MSPs after the move. The graph in the bottom panel of Figure 1, which is based on the predicted probability of enrolling in an MSP, provides a different story. This figure presents average expenditures for the $1^{\text {st }}$ and $4^{\text {th }}$ quartiles of the predicted probability of enrolling in either a SSP or MSP based on the share of a given type of organization in the destination HRR. The increase among those likely to stay in SSP is larger than the increase in spending among those likely to change. This dynamic underlies the IV estimate of a negative effect of MSP on spending. The dynamic is similar for beneficiaries who are in MSPs prior to the move (Figure 2). The change in total expenditure between the pre- and post-move time periods is similar for the two groups based on their observed switching behavior. The difference in 
changes over time is greater between the two groups, in contrast, based on the predicted probability of switching to SSP with the change greater among those with a high probability of switching

A possible explanation for the difference between the OLS and IV results is that beneficiaries whose health declined more around the time of the move were more likely to choose multispecialty practices after the move. When we instrument for actual practice type switch with share of practice type in the destination HRR, that source of endogeneity would be removed, revealing that MSPs have lower costs per patient than single specialty practices. In other words, among patients who move and choose a new practice, MSPs differentially attract those whose health is deteriorating.

The results in Table 3 also suggest that changes in market conditions were not a threat to validity in this context. Neither the OLS nor the IV results are sensitive to including HRR*Year as opposed to HRR and Year fixed effects. The HRR*Year fixed effects control for many possible changes in market conditions that have potential to bias the estimates such as markets with a growing share of very large practices, markets becoming increasingly concentrated, and markets experiencing physician integration with hospitals. The similarity between the estimates from models with and without the HRR*Year fixed effects suggest that these types of factors were not substantive sources of bias in this analysis. The main limitation of the model with HRR-by-year fixed effects is that the precision of the estimates declines. Thus, while we present the results of models including HRR-by-year fixed effects in the main tables as our preferred specification since they control for both potential sources of bias, we also include the results of models with HRR and year fixed effects in the appendix for comparison.

\section{The Effects of Physician Practice Type by Type of Spending and by Subpopulation}


Table 5 illustrates that that these effects are primarily concentrated in expenditures for hospitalizations as compared to physician or outpatient services. The effects on hospital expenditures are largest on both an absolute percentage basis. The estimates indicate that a switch from SSP to MSP decreases hospital expenditures by $\$ 1,406$, a $58 \%$ reduction relative to baseline expenditures. Similarly, a switch in the other direction, from MSP to SSP increases hospital expenditures by $\$ 1,536$. The effects on physician services are generally smaller and not statistically significant. Those for outpatient services are in the same direction as the effects on hospital services, but the estimates are imprecise.

One potential mechanism to explain this result could be that coordination of care within a MSP helps keep patients out of the hospital. To explore that possibility, we next look at the effect of practice type on hospitalizations. The results in Table 6 support the hypothesis that MSPs are more effective at keeping their patients out of the hospital. The results suggest that for patients associated with a MSP before the move, switching to a single specialty practice after the move increases the probability of having at least one hospitalization in the year after by about $23 \%$ relative to staying in a MSP. The increased probability of having two or more hospitalizations is over $80 \%$. While moving from a SSP to a MSP reduces the probability of both any hospitalization and two or more hospitalizations, the estimated effects are smaller in magnitude and not statistically significant. Lower hospitalizations by MSPs is consistent with the idea that integration lowers the costs of consultation among physicians of different specialties for patients with complex conditions.

We also examine if our results are driven by, for example, the very sick or the very old, given that there may be greater opportunity to coordinate care among less healthy patients. In Table 7, we estimate models of total expenditures separately by number of chronic conditions $(0-2$ and $>2)$ and age (65-75 and > 75). As we see in Table 7, the expenditure declines in MSP and increases in single specialty practices are larger for those with more than two chronic conditions; however, the point 
estimates suggest that cost savings at MSPs relative to single specialty practices are also seen for those with fewer than three chronic conditions. Larger effects for those with more chronic conditions is again consistent with the idea that practice integration across specialties lowers the cost of coordination by primary care physicians and specialists, since such coordination is likely to be of greatest value for those with complex health problems such as those with multiple chronic conditions. The effects of physician practice type are more precise in the models without HRR-byyear fixed effects (Appendix Table 4).

Table 7 also includes results for models run separately for those aged 65-75 and those over age 75 . While only two of the four key results remain statistically significant in these smaller samples, the patterns remain the same and the point estimates are similar for the two age groups. Once again we see that once we instrument for switching practice types, those moving to MSPs have lower expenditures and vice-versa for those switching to single specialty practices. The effects are not disproportionately concentrated among either the younger or the older elderly.

In Table 8 - Columns 3 and 4, we explore the sensitivity of our results to the definition of practice type. In particular, we accentuate the difference in practice types by dropping observations of relatively large SSPs and relatively small MSPs. This potentially makes a cleaner comparison between the two types of practices. Columns 1 and 2 repeat main estimates from Table 3 for comparison. When we restrict the two group types by size as described above, the results are similar, although the positive effect of moving from MSP to SSP is larger and the negative effect of moving from SSP to MSP is smaller and less precise. But, overall, the effects continue to be large in magnitude and in the same direction.

In Table 8 -Columns 5-8, we also examine whether the effect we observe varies based on the level of Medicare Advantage penetration in the market of the beneficiary. We hypothesized that any negative effects on expenditures could be driven by spillovers from MA to traditional Medicare. We 
find little evidence to support this as a mechanism driving our results. While the estimates are less precise due to the smaller sample size in each group, they are similar in magnitude in both low and high penetration areas.

\section{$\underline{\text { Conclusions }}$}

In this paper, we investigate the effect of multispecialty practice organization on the costs and use of health care by Medicare FFS beneficiaries. Using a difference-in-difference approach in combination with an instrumental variables strategy, we focus our analysis on people with an abrupt change in their primary care physician due to a geographic move and address the issue of selection into practice type after the move. We find that controlling for patient selection into practice type is quite important. Results from OLS difference-in-differences models are very different from the IV DD results. It appears that patients whose health is changing for the worse around the time of a geographic move are more likely to choose primary care physicians working in MSPs, causing bias in the OLS estimates and making it appear that MSPs are more costly.

Once we address selection into practice type at the time of the move, we find that expenditures are lower for patients whose primary care physicians work in MSPs that for those whose primary care physician is in a SSP. The IV DD models also produce approximately symmetric estimates for the two types of move: that is, the cost savings when moving to a MSPs are approximately equal to the cost increases when moving to a single specialty practice. While such symmetry in the size of the effect would be expected under standard assumptions, we do not observe that symmetry with OLS, giving further credence to the IV results. The results are robust to a number of sensitivity checks.

While MSP has the potential to reduce health care costs through greater coordination of care in the form of, for example, less duplication of services or better management of chronic conditions, 
there is little evidence in the existing literature that it achieves these types of efficiencies. Our study, in contrast, suggests that MSP lowers health care spending primarily by reducing inpatient hospitalizations. While we do not provide direct evidence of the mechanism underlying our result, this finding is consistent with MSP providing better management of patients with chronic conditions, particularly since the effect is concentrated among people with two or more chronic conditions. We did not find evidence that MSP used its ability to coordinate care to increase referrals to specialist or the use of other types of care that would ultimately increase Medicare payments.

In summary, our results suggest that MSPs may lower health care spending, providing some evidence in support of potential benefits from the formation of larger health care organizations. Thus, any increases in prices due to greater market power must be viewed against reduction in costs due to lower health care use. An important consideration is the effect on health care quality and patient outcomes. Additional research should address the implications of lower spending on health care services for patient health. 


\section{References:}

Baicker, K., Levy, H., 2013. Coordination versus Competition in Health Care Reform. N. Engl. J. Med. 369, 789-791.

Baker, L.C., 1997. The effect of HMOs on fee-for-service health care expenditures: evidence from Medicare. J. Health Econ. 16, 453-481.

Baker, L.C., Bundorf, M.K., Kessler, D.P., 2014a. Vertical integration: hospital ownership of physician practices is associated with higher prices and spending. Health Aff. (Millwood). 33. https://doi.org/10.1377/hlthaff.2013.1279

Baker, L.C., Bundorf, M.K., Royalty, A.B., 2018. Measuring Physician Practice Competition Using Medicare Data, in: Aizcorbe, A., Baker, C., Berndt, E., Cutler, D. (Eds.), Measuring and Modeling Health Care Costs. University of Chicago Press.

Baker, L.C., Bundorf, M.K., Royalty, A.B., Levin, Z., 2014b. Physician practice competition and prices paid by private insurers for office visits. JAMA - J. Am. Med. Assoc. 312. https://doi.org/10.1001/jama.2014.10921

Bradford, W.D., Martin, R.E., 2000. Partnerships, profit sharing, and quality competition in the medical profession. Rev. Ind. Organ. 17, 193-208. https://doi.org/10.1023/A:1007894428368

Bresnahan, T.F., Levin, J.D., 2012. Vertical Integration and Market Structure, in: Gibbons, R., Roberts, J. (Eds.), The Handbook of Organizational Economics. Princeton University Press, pp. 853-890. https://doi.org/10.1017/CBO9781107415324.004

Burns, L.R., Goldsmith, J.C., Sen, A., 2013. Horizontal and vertical integration of physicians: A tale of two tails. Adv. Health Care Manag. 15, 39-117. https://doi.org/10.1108/S14748231(2013)0000015009

Casalino, L.P., Devers, K.J., Lake, T.K., Reed, M., Stoddard, J.J., 2003. Benefits of and barriers to large medical group practice in the United States. Arch. Intern. Med. 163, 1958-1964. https://doi.org/10.1001/archinte.163.16.1958

Casalino, L.P., Pesko, M.F., Ryan, A.M., Mendelsohn, J.L., Copeland, K.R., Ramsay, P.P., Sun, X., Rittenhouse, D.R., Shortell, S.M., 2014. Small primary care physician practices have low rates of preventable hospital admissions. Health Aff. 33, 1680-1688. https://doi.org/10.1377/hlthaff.2014.0434

Casalino, L.P., Ramsay, P., Baker, L.C., Pesko, M.F., Shortell, S.M., 2018. Medical Group Characteristics and the Cost and Quality of Care for Medicare Beneficiaries. Health Serv. Res. https://doi.org/10.1111/1475-6773.13010

Chen, Y., Levin, J., Einav, L., 2019. Consolidation of Primary Care Physicians and Its Impact on Healthcare Utilization.

Chernew, M., DeCicca, P., Town, R., 2008. Managed care and medical expenditures of Medicare beneficiaries. J. Health Econ. 27, 1451-1461. https://doi.org/10.1016/j.jhealeco.2008.07.014

CMS, 2014. Medicare Shared Savings Program Shared Savings and Losses and Assignment Methodology Specifications. Baltimore, MD.

Dunn, A., Shapiro, A., 2014. Do physicians possess market power? J. Law Econ. 57, 159-193. https://doi.org/10.1086/674407

Finkelstein, A., Gentzkow, M., Williams, H., 2016. Sources of Geographic Variation in Health Care : Evidence From Patient Migration. Q. J. Econ. 1681-1726. https://doi.org/10.1093/qje/qjw023.Advance

Fuchs, V.R., 1998. Who Shall Live? Health, Economics and Social Choice, Expanded. ed. World Scientific Publishing Co., River Edge, NJ.

Gans, D., Kralewski, J., Hammons, T., Dowd, B., 2005. Medical groups' adoption of electronic health records and information systems. Health Aff. 24, 1323-1333. 
https://doi.org/10.1377/hlthaff.24.5.1323

Garicana, L., Santos, T., 2010. Referrals. Am. Econ. Rev. 94, 499-525.

Gaynor, M., Gertler, P., 1995. Moral Hazard and Risk Spreading in Partnerships. Rand J. Econ. 26, 591-613.

Gaynor, M., Rebitzer, J.B., Taylor, L.J., 2004. Physician Incentives in Health Maintenance Organizations. J. Polit. Econ. 112, 915-931.

Hart, O., Holmstrom, B., 2010. A Theory of Firm Scope. Q. J. Econ. CXXV, pp 483-513.

McWilliams, J.M., Landon, B.E., Chernew, M.E., 2013. Changes in health care spending and quality for Medicare beneficiaries associated with a commercial ACO contract. JAMA 310, 829-36. https://doi.org/10.1001/jama.2013.276302

Rebitzer, J.B., Votruba, M.E., 2014. Organizational Economics and Physician Practices, in: Culyer, A.J. (Ed.), Encyclopedia of Health Economics. Elsevier, San Diego, pp. 414-424. https://doi.org/https://doi.org/10.1016/B978-0-12-375678-7.01112-3

Weeks, W., Gottlieb, D., Nyweide, D., Sutherland, J., Bynum, J., Casalino, L., Gillies, R., Shortell, S., Fisher, E., 2010. Higher health care quality and bigger savings found at large multispecialty medical groups [corrected] [published erratum appears in HEALTH AFF 2010 Jun;29(6):12756]. Health Aff. 29, 991-997. https://doi.org/10.1377/hlthaff.2009.0388

Whinston, M., 2007. Antitrust Policy toward Horizontal Mergers, in: Armstrong, Mark and Porter, R. (Ed.), Handbook of Industrial Organization, Vol. 3. Elsevier, pp. 2369-2440. 
Figure 1: Total Annual Per Capita Health Expenditures Pre- and Post-Move by Observed and Predicted Probability of Switching Practice Type among Beneficiaries in SSP Prior to Move
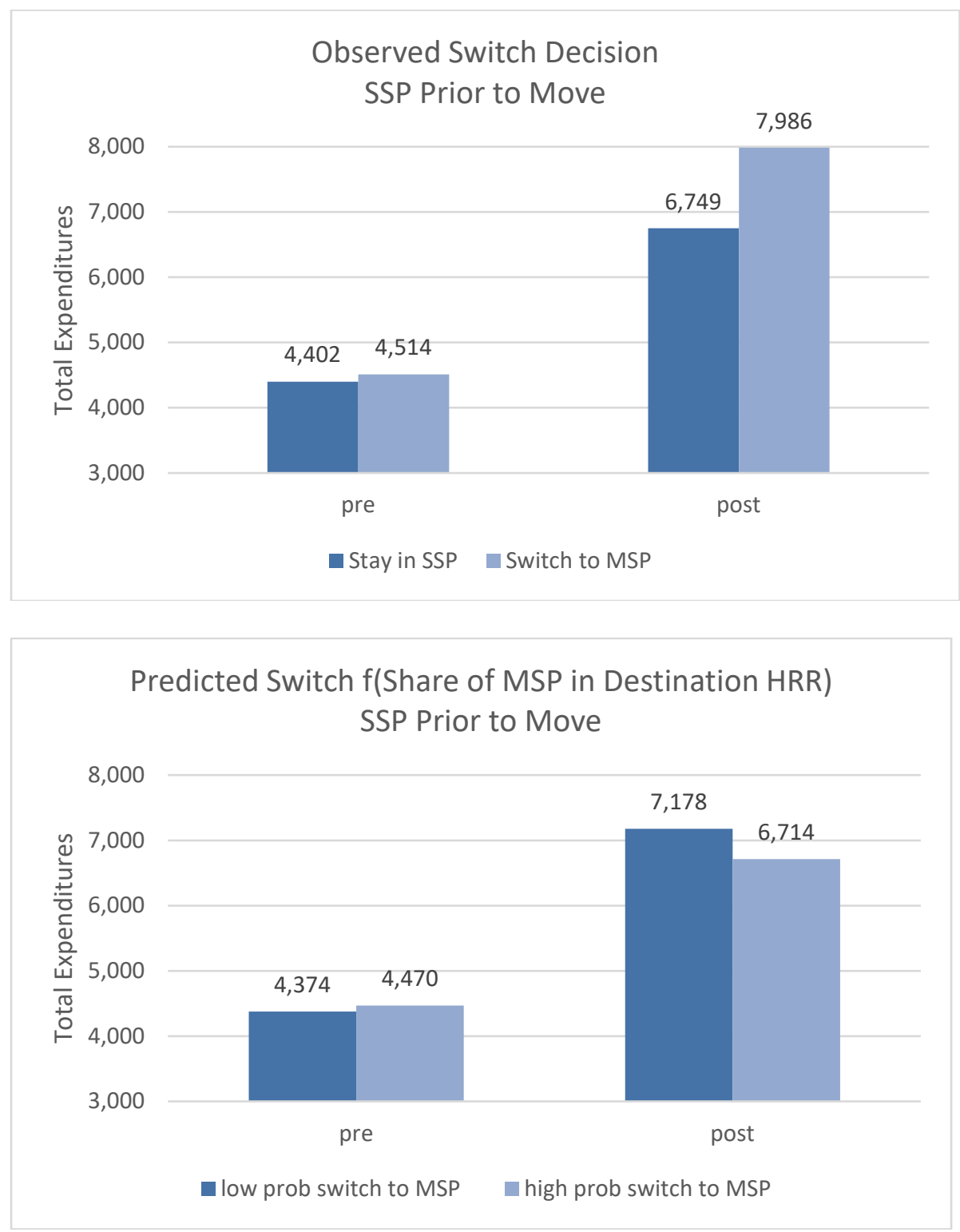

Note: The top panel presents average expenditures prior to and after the move among people with a SSP primary care physician prior to the move by their primary care physician's practice setting after the move. The bottom presents the same information by the predicted probability of seeing a primary care physician in a MSP after the move as a function of the MSP market share in the destination HRR, restricting to the $1^{\text {st }}$ and $4^{\text {th }}$ quartiles of the distribution of predicted probabilities. 
Figure 2: Total Annual Per Capita Health Expenditures Pre- and Post-Move by Observed and Predicted Probability of Switching Practice Type among Beneficiaries in MSP Prior to Move
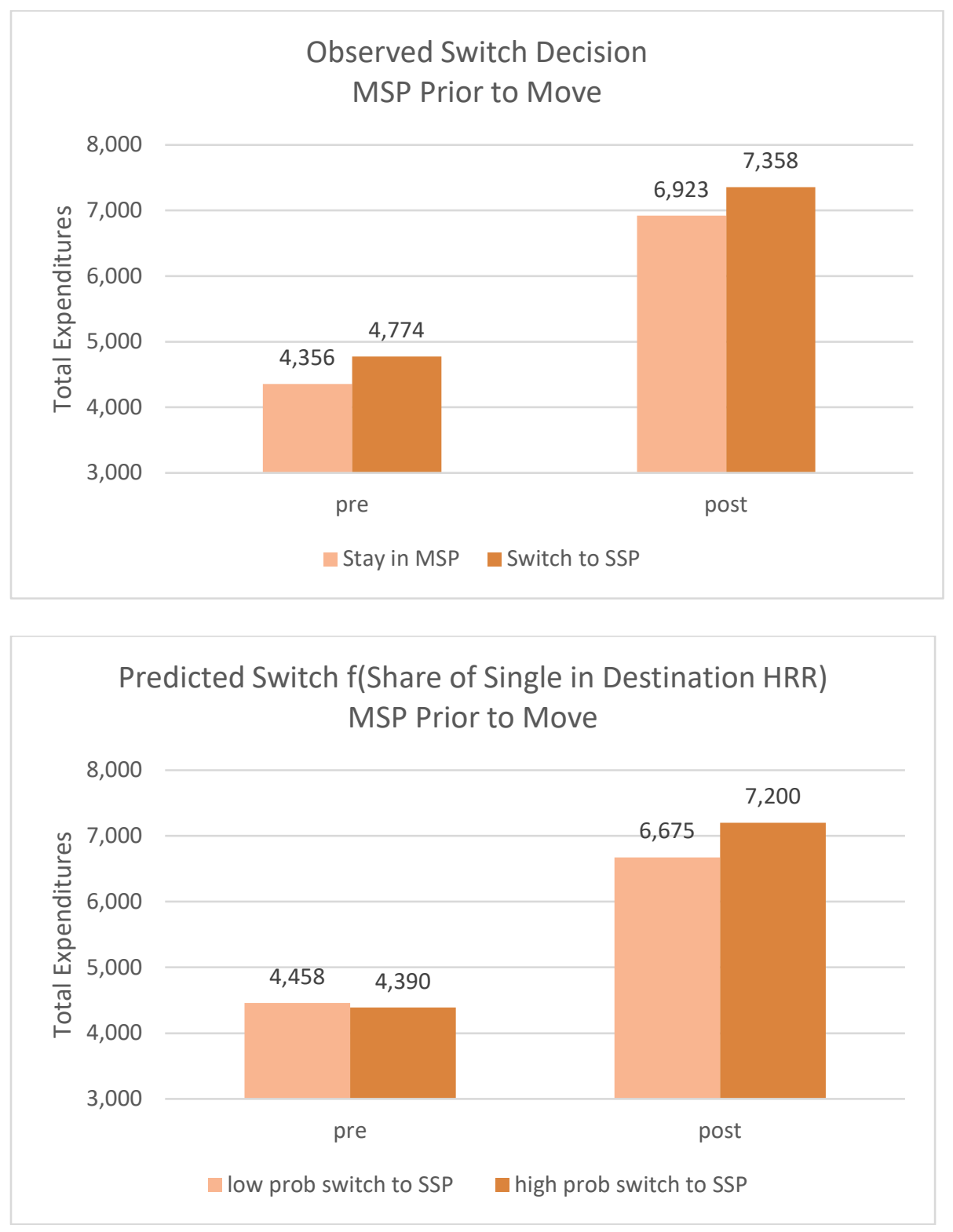

Note: The top panel presents average expenditures prior to and after the move among people with a MSP primary care physician prior to the move by their primary care physician's practice setting after the move. The bottom presents the same information by the predicted probability of seeing a primary care physician in a SSP after the move as a function of the SSP market share in the destination HRR, restricting to the $1^{\text {st }}$ and $4^{\text {th }}$ quartiles of the distribution of predicted probabilities. 
Table 1: Study Sample Summary Statistics

\begin{tabular}{|c|c|c|}
\hline & Non-Movers & Movers \\
\hline & $(1)$ & $(2)$ \\
\hline \multicolumn{3}{|l|}{ Age } \\
\hline Mean & 75.26 & 76.00 \\
\hline SD & 7.30 & 7.17 \\
\hline Male & 0.40 & 0.35 \\
\hline Non-White & 0.12 & 0.08 \\
\hline \multicolumn{3}{|l|}{ Region of residence } \\
\hline Midwest & 0.27 & 0.21 \\
\hline Northeast & 0.20 & 0.18 \\
\hline South & 0.38 & 0.43 \\
\hline West & 0.15 & 0.18 \\
\hline \multicolumn{3}{|l|}{ Health Conditions } \\
\hline Atrial Fibrillation & 0.07 & 0.07 \\
\hline Kidney Disease & 0.06 & 0.04 \\
\hline Chronic Obstructive Pulmonary Disease & 0.10 & 0.09 \\
\hline Heart Failure & 0.15 & 0.12 \\
\hline Diabetes & 0.20 & 0.17 \\
\hline Heart Disease & 0.29 & 0.28 \\
\hline Arthritis & 0.24 & 0.24 \\
\hline Asthma & 0.03 & 0.03 \\
\hline High Cholesterol & 0.35 & 0.33 \\
\hline Hypertension & 0.51 & 0.49 \\
\hline \multicolumn{3}{|l|}{ Number of Chronic Conditions } \\
\hline Mean & 2.00 & 1.86 \\
\hline SD & 1.76 & 1.64 \\
\hline$\#$ patients & $9,400,843$ & 119,272 \\
\hline
\end{tabular}

Notes: Both samples are restricted to people $>65$ and $<99$, with both Medicare Parts A and $\mathrm{B}$ and no Medicare Advantage enrollment for each month of the study period. Non-movers include of $25 \%$ random sample of those who remained in the same HRR during the study period. Movers include those identified as movers based on the criteria outlined in the text. Variables represent patient characteristics in the year prior to the move. 
Table 2a: Descriptive Statistics - Movers, Overall and by Practice Type Change

\begin{tabular}{|c|c|c|c|c|c|}
\hline & (1) & $(2)$ & (3) & (4) & (5) \\
\hline & All & $\begin{array}{c}\text { SSP - No } \\
\text { Change }\end{array}$ & $\begin{array}{c}\text { SSP to } \\
\text { MSP }\end{array}$ & $\begin{array}{c}\text { MSP - } \\
\text { No } \\
\text { Change }\end{array}$ & $\begin{array}{c}\text { MSP to } \\
\text { SSP }\end{array}$ \\
\hline \multicolumn{6}{|l|}{ Age } \\
\hline $65-74$ & 0.45 & 0.45 & 0.43 & 0.46 & 0.43 \\
\hline $75-84$ & 0.42 & 0.42 & 0.43 & 0.41 & 0.43 \\
\hline$>=85$ & 0.14 & 0.13 & 0.14 & 0.13 & 0.15 \\
\hline Male & 0.35 & 0.34 & 0.35 & 0.36 & 0.35 \\
\hline Non White & 0.08 & 0.09 & 0.08 & 0.07 & 0.08 \\
\hline \multicolumn{6}{|l|}{ Residence } \\
\hline Midwest & 0.21 & 0.17 & 0.19 & 0.30 & 0.22 \\
\hline Northeast & 0.18 & 0.20 & 0.18 & 0.16 & 0.18 \\
\hline South & 0.43 & 0.43 & 0.44 & 0.39 & 0.45 \\
\hline West & 0.18 & 0.20 & 0.19 & 0.15 & 0.15 \\
\hline \multicolumn{6}{|l|}{ Health Conditions } \\
\hline Atrial Fibrillation & 0.07 & 0.06 & 0.07 & 0.07 & 0.07 \\
\hline Kidney Disease & 0.04 & 0.04 & 0.04 & 0.04 & 0.04 \\
\hline COPD & 0.09 & 0.09 & 0.10 & 0.08 & 0.09 \\
\hline Heart Failure & 0.12 & 0.12 & 0.14 & 0.11 & 0.12 \\
\hline Diabetes & 0.17 & 0.17 & 0.18 & 0.17 & 0.17 \\
\hline Heart Disease & 0.28 & 0.29 & 0.30 & 0.27 & 0.29 \\
\hline Arthritis & 0.24 & 0.24 & 0.25 & 0.23 & 0.23 \\
\hline Asthma & 0.03 & 0.03 & 0.03 & 0.03 & 0.03 \\
\hline High Cholesterol & 0.33 & 0.33 & 0.34 & 0.33 & 0.31 \\
\hline Hypertension & 0.49 & 0.49 & 0.50 & 0.48 & 0.48 \\
\hline \multicolumn{6}{|l|}{ \# of Chronic Conditions } \\
\hline $0-2$ & 0.69 & 0.69 & 0.67 & 0.70 & 0.69 \\
\hline$>2$ & 0.31 & 0.31 & 0.33 & 0.30 & 0.31 \\
\hline \# Patients & 119,272 & 47,366 & 23,603 & 28,850 & 19,453 \\
\hline Share of Movers & 1.00 & 0.40 & 0.20 & 0.24 & 0.16 \\
\hline
\end{tabular}

Notes: Sample of movers is constructed as described in the text and in Table 1. SSP and MSP represent single and multi-specialty practice. Columns 2-5 present descriptive statistics for subsets of the mover sample based on whether they change between MSP and SSP and in which direction when they move. 
Table 2b: Descriptive Statistics - Movers, Overall and by Practice Type Change

\begin{tabular}{|c|c|c|c|c|c|}
\hline & $(1)$ & $(2)$ & (3) & (4) & $(5)$ \\
\hline & All & $\begin{array}{l}\text { SSP - No } \\
\text { Change }\end{array}$ & $\begin{array}{l}\text { SSP to } \\
\text { MSP }\end{array}$ & $\begin{array}{c}\text { MSP - } \\
\text { No } \\
\text { Change }\end{array}$ & $\begin{array}{l}\text { MSP to } \\
\text { SSP }\end{array}$ \\
\hline \multicolumn{6}{|l|}{ Practice Composition } \\
\hline Share SSP & 0.60 & 1.00 & 1.00 & 0.00 & 0.00 \\
\hline Share MSP & 0.41 & 0.00 & 0.00 & 1.00 & 1.00 \\
\hline Number of Physicians & 39.94 & 5.13 & 5.74 & 97.89 & 80.24 \\
\hline Number of Specialties & 3.36 & 1.00 & 1.00 & 7.07 & 6.44 \\
\hline \multicolumn{6}{|l|}{ Health Care Expenditures } \\
\hline Total & 4,424 & 4,157 & 4,514 & 4,553 & 4,774 \\
\hline Physician & 1,656 & 1,619 & 1,717 & 1,659 & 1,670 \\
\hline Hospital & 2,405 & 2,230 & 2,414 & 2,468 & 2,727 \\
\hline Outpatient & 363 & 308 & 382 & 426 & 377 \\
\hline \multicolumn{6}{|l|}{ Health Care Utilization } \\
\hline Any Hospitalization & 0.20 & 0.19 & 0.21 & 0.21 & 0.23 \\
\hline$>1$ Hospitalization & 0.06 & 0.06 & 0.07 & 0.06 & 0.07 \\
\hline HRR Penetration & 0.23 & 0.23 & 0.23 & 0.23 & 0.22 \\
\hline \# patients & 119,272 & 47,366 & 23,603 & 28,850 & 19,453 \\
\hline Share of movers & 1.00 & 0.40 & 0.20 & 0.24 & 0.16 \\
\hline
\end{tabular}

Notes: Sample of movers is constructed as described in the text and in Table 1. SSP and MSP represent single and multi-specialty practice. Columns 2-5 present descriptive statistics for subsets of the mover sample based on whether they change between MSP and SSP and in which direction when they move. 
Table 3: Difference-in-Difference Estimates of the Effect Primary Care Group Composition on Total Expenditures

\begin{tabular}{|c|c|c|c|c|c|c|c|c|}
\hline & \multicolumn{8}{|c|}{ Dependent Variable: Total Expenditures } \\
\hline & \multicolumn{4}{|c|}{ OLS } & \multicolumn{4}{|c|}{ IV } \\
\hline & $\begin{array}{c}\text { SSP } \\
\text { before } \\
\text { Move } \\
(1)\end{array}$ & $\begin{array}{c}\text { MSP } \\
\text { before } \\
\text { Move } \\
(2)\end{array}$ & $\begin{array}{c}\text { SSP } \\
\text { before } \\
\text { Move } \\
(3)\end{array}$ & $\begin{array}{l}\text { MSP } \\
\text { before } \\
\text { Move } \\
(4)\end{array}$ & $\begin{array}{c}\text { SSP } \\
\text { before } \\
\text { Move } \\
(5)\end{array}$ & $\begin{array}{c}\text { MSP } \\
\text { before } \\
\text { Move } \\
(6)\end{array}$ & $\begin{array}{c}\text { SSP } \\
\text { before } \\
\text { Move } \\
(7)\end{array}$ & $\begin{array}{c}\text { MSP } \\
\text { before } \\
\text { Move } \\
(8)\end{array}$ \\
\hline Single to MSP Switcher*Post & $\begin{array}{c}1,085^{* * *} \\
(118.9)\end{array}$ & & $\begin{array}{c}1,142^{* * *} \\
(120.8)\end{array}$ & & $\begin{array}{c}-1,610 * * \\
(640.1)\end{array}$ & & $\begin{array}{c}-1,553^{* *} \\
(765.6)\end{array}$ & \\
\hline MSP to Single Switcher*Post & & $\begin{array}{c}143.5 \\
(143.6)\end{array}$ & & $\begin{array}{c}210.4 \\
(146.8)\end{array}$ & & $\begin{array}{c}1,638^{* * *} \\
(633.8)\end{array}$ & & $\begin{array}{l}1,636 \text { ** } \\
(704.6)\end{array}$ \\
\hline Single to MSP Switcher & $\begin{array}{c}247.3^{* * *} \\
(83.56)\end{array}$ & & $\begin{array}{c}237.8^{* * *} \\
(84.43)\end{array}$ & & $\begin{array}{c}18.25 \\
(376.6)\end{array}$ & & $\begin{array}{c}50.45 \\
(383.8)\end{array}$ & \\
\hline MSP to Single Switcher & & $\begin{array}{c}91.33 \\
(101.5)\end{array}$ & & $\begin{array}{c}60.47 \\
(103.1)\end{array}$ & & $\begin{array}{l}-441.8 \\
(453.5)\end{array}$ & & $\begin{array}{l}-326.7 \\
(462.1)\end{array}$ \\
\hline Post & $\begin{array}{c}1,229 * * * \\
(75.55) \\
\end{array}$ & $\begin{array}{c}934.2^{* * *} \\
(98.44) \\
\end{array}$ & $\begin{array}{c}1,236 \text { *** } \\
(76.57)\end{array}$ & $\begin{array}{c}914.8^{* * *} \\
(100.4)\end{array}$ & $\begin{array}{c}2,028^{* * *} \\
(212.1) \\
\end{array}$ & $\begin{array}{c}358.0 \\
(257.4) \\
\end{array}$ & $\begin{array}{c}2,028^{* * *} \\
(245.3) \\
\end{array}$ & $\begin{array}{r}367.8 \\
(282.7) \\
\end{array}$ \\
\hline HRR and Year Fixed Effects & $\mathrm{Y}$ & $\mathrm{Y}$ & $\mathrm{N}$ & $\mathrm{N}$ & Y & $\mathrm{Y}$ & $\mathrm{N}$ & $\mathrm{N}$ \\
\hline HRR by Year Fixed Effects & $\mathrm{N}$ & $\mathrm{N}$ & Y & $\mathrm{Y}$ & $\mathrm{N}$ & $\mathrm{N}$ & $\mathrm{Y}$ & $\mathrm{Y}$ \\
\hline Instrumented & $\mathrm{N}$ & $\mathrm{N}$ & $\mathrm{N}$ & $\mathrm{N}$ & $\mathrm{Y}$ & $\mathrm{Y}$ & $\mathrm{Y}$ & $\mathrm{Y}$ \\
\hline Pre-Move Mean & 4,514 & 4,774 & 4,514 & 4,774 & 4,514 & 4,774 & 4,514 & 4,774 \\
\hline Change $(\%)$ & $24 \%$ & $3 \%$ & $25 \%$ & $4 \%$ & $-36 \%$ & $34 \%$ & $-34 \%$ & $34 \%$ \\
\hline No. of patients & 70,969 & 48,303 & 70,969 & 48,303 & 70,969 & 48,303 & 70,935 & 48,251 \\
\hline No. of patient-years & 141,938 & 96,606 & 141,938 & 96,606 & 141,938 & 96,606 & 141,869 & 96,502 \\
\hline
\end{tabular}


Table 4: Analysis of Movement into and out of HRRs

\begin{tabular}{|c|c|c|c|c|c|}
\hline & $\mathrm{N}$ & Mean & S.D. & Minimum & Maximum \\
\hline Number of person-year observations per HRR-Year & 3,661 & 65.16 & 77.08 & 1.00 & 918.00 \\
\hline Share of person-years observations that are a destination observation & 3,661 & 0.54 & 0.31 & 0.00 & 1.00 \\
\hline Number of unique origins when HRR-Year is observed as a destination. & 3,049 & 33.04 & 29.24 & 1.00 & 193.00 \\
\hline
\end{tabular}

Notes: This analysis is based on a dataset in which each observation represents an HRR is a particular year. Statistics are based on HRR-year level analysis. The number of HRR-years varies across the measures since some HRR-years are observed only as origins and other are observed only as destinations. 
Table 5: Difference-in-Difference IV Estimates of the Effect Primary Care Group Composition on Expenditures by Type

\begin{tabular}{|c|c|c|c|c|c|c|}
\hline & \multicolumn{6}{|c|}{ Dependent Variable: Type of Expenditures } \\
\hline & \multicolumn{3}{|c|}{ SSP before Move } & \multicolumn{3}{|c|}{ MSP before Move } \\
\hline & $\begin{array}{c}\text { Physician } \\
\text { (1) }\end{array}$ & $\begin{array}{c}\text { Hospital } \\
(2)\end{array}$ & $\begin{array}{c}\text { Outpatient } \\
\text { (3) }\end{array}$ & $\begin{array}{c}\text { Physician } \\
\text { (4) }\end{array}$ & $\begin{array}{c}\text { Hospital } \\
\text { (5) }\end{array}$ & $\begin{array}{c}\text { Outpatient } \\
(6)\end{array}$ \\
\hline Single to MSP Switcher*Post & $\begin{array}{c}4.213 \\
(158.3)\end{array}$ & $\begin{array}{c}-1,406^{* *} \\
(639.9)\end{array}$ & $\begin{array}{l}-152.0 \\
(125.1)\end{array}$ & & & \\
\hline MSP to Single Switcher*Post & & & & $\begin{array}{c}154.9 \\
(135.9)\end{array}$ & $\begin{array}{c}1,536 * * * \\
(594.7)\end{array}$ & $\begin{array}{l}-54.80 \\
(117.0)\end{array}$ \\
\hline Single to MSP Switcher & $\begin{array}{c}101.2 \\
(79.35)\end{array}$ & $\begin{array}{l}-117.5 \\
(320.8)\end{array}$ & $\begin{array}{c}66.73 \\
(62.71)\end{array}$ & & & \\
\hline MSP to Single Switcher & & & & $\begin{array}{l}-51.53 \\
(89.12)\end{array}$ & $\begin{array}{l}-367.6 \\
(390.1)\end{array}$ & $\begin{array}{c}92.35 \\
(76.72)\end{array}$ \\
\hline Post & $\begin{array}{c}338.9 \text { *** } \\
(50.72) \\
\end{array}$ & $\begin{array}{c}1,536^{* * *} \\
(205.0)\end{array}$ & $\begin{array}{c}153.7 * * * \\
(40.08)\end{array}$ & $\begin{array}{c}151.8^{* * *} \\
(54.52) \\
\end{array}$ & $\begin{array}{c}125.2 \\
(238.6) \\
\end{array}$ & $\begin{array}{l}90.81 * \\
(46.93) \\
\end{array}$ \\
\hline HRR and Year Fixed Effects & $\mathrm{N}$ & $\mathrm{N}$ & $\mathrm{N}$ & $\mathrm{N}$ & $\mathrm{N}$ & $\mathrm{N}$ \\
\hline HRR by Year Fixed Effects & $\mathrm{Y}$ & $\mathrm{Y}$ & $\mathrm{Y}$ & Y & $\mathrm{Y}$ & $\mathrm{Y}$ \\
\hline Instrumented & $\mathrm{Y}$ & Y & Y & $\mathrm{Y}$ & $\mathrm{Y}$ & Y \\
\hline Pre-Move Mean & 1,717 & 2,414 & 382 & 1,670 & 2,727 & 377 \\
\hline Change $(\%)$ & $0 \%$ & $-58 \%$ & $-40 \%$ & $9 \%$ & $56 \%$ & $-15 \%$ \\
\hline No. of patients & 70,935 & 70,935 & 70,935 & 48,251 & 48,251 & 48,251 \\
\hline No. of patient-years & 141,869 & 141,869 & 141,869 & 96,502 & 96,503 & 96,504 \\
\hline
\end{tabular}

Notes: ${ }^{* *} \mathrm{p}<0.01,{ }^{* *} \mathrm{p}<0.05,{ }^{*} \mathrm{p}<0.1$. All models include controls for chronic conditions, age, sex, race, and year. Standard errors are in parentheses. Construction of sample of movers is described in the text. SSP and MSP represent single and multi-specialty practice. 
Table 6: Difference-in-Difference IV Estimates of the Effect Primary Care Group Composition on Hospitalizations

\begin{tabular}{|c|c|c|c|c|}
\hline & \multicolumn{4}{|c|}{ Dependent Variable: Hospitalizations } \\
\hline & \multicolumn{2}{|c|}{ SSP before Move } & \multicolumn{2}{|c|}{ MSP before Move } \\
\hline & $\begin{array}{c}1 \text { or More } \\
\text { Hosp } \\
(1)\end{array}$ & $\begin{array}{c}2 \text { or More } \\
\text { Hosp } \\
(2)\end{array}$ & $\begin{array}{c}1 \text { or More } \\
\text { Hosp } \\
(3)\end{array}$ & $\begin{array}{c}2 \text { or More } \\
\text { Hosp } \\
(4)\end{array}$ \\
\hline Single to MSP Switcher*Post & $\begin{array}{l}-0.0149 \\
(0.0298)\end{array}$ & $\begin{array}{l}-0.0169 \\
(0.0201)\end{array}$ & & \\
\hline MSP to Single Switcher*Post & & & $\begin{array}{c}0.0622^{* *} \\
(0.0268)\end{array}$ & $\begin{array}{c}0.0609 * * * \\
(0.0180)\end{array}$ \\
\hline Single to MSP Switcher & $\begin{array}{c}0.0150 \\
(0.0149)\end{array}$ & $\begin{array}{c}-0.000528 \\
(0.0101)\end{array}$ & & \\
\hline MSP to Single Switcher & & & $\begin{array}{l}-0.0263 \\
(0.0176)\end{array}$ & $\begin{array}{l}-0.0153 \\
(0.0118)\end{array}$ \\
\hline Post & $\begin{array}{c}0.0613^{* * *} \\
(0.00953) \\
\end{array}$ & $\begin{array}{c}0.0444 * * * \\
(0.00643) \\
\end{array}$ & $\begin{array}{c}0.0160 \\
(0.0108) \\
\end{array}$ & $\begin{array}{c}0.00471 \\
(0.00724)\end{array}$ \\
\hline HRR and Year Fixed Effects & $\mathrm{N}$ & $\mathrm{N}$ & $\mathrm{N}$ & $\mathrm{N}$ \\
\hline HRR by Year Fixed Effects & $\mathrm{Y}$ & $\mathrm{Y}$ & $\mathrm{Y}$ & $\mathrm{Y}$ \\
\hline Instrumented & $\mathrm{Y}$ & $\mathrm{Y}$ & Y & $\mathrm{Y}$ \\
\hline Pre-Move Mean & 0.21 & 0.07 & 0.23 & 0.07 \\
\hline Change $(\%)$ & $-7 \%$ & $-26 \%$ & $28 \%$ & $82 \%$ \\
\hline No. of patients & 70,935 & 70,935 & 48,251 & 48,251 \\
\hline No. of patient-years & 141,869 & 141,869 & 96,502 & 96,502 \\
\hline
\end{tabular}

Notes: $* * * \mathrm{p}<0.01, * * \mathrm{p}<0.05, * \mathrm{p}<0.1$. All models include controls for chronic conditions, age, sex, race, and year. Standard errors are in parentheses. Construction of sample of movers is described in the text. SSP and MSP represent single and multi-specialty practice. 
Table 7: Estimates of the Effect Primary Care Group Composition on Total Expenditures by Health Status and Age

\begin{tabular}{|c|c|c|c|c|c|c|c|c|}
\hline & \multicolumn{8}{|c|}{ Dependent Variable: Total Expenditures } \\
\hline & \multicolumn{4}{|c|}{ SSP before Move } & \multicolumn{4}{|c|}{ MSP before Move } \\
\hline & $\begin{array}{c}\text { 0-2 Chronic } \\
\text { Conditions }\end{array}$ & $\begin{array}{c}>2 \\
\text { Chronic } \\
\text { Conditions }\end{array}$ & Age 65-74 & Age $>75$ & $\begin{array}{c}0-2 \\
\text { Chronic } \\
\text { Conditions } \\
\end{array}$ & $\begin{array}{c}>2 \\
\text { Chronic } \\
\text { Conditions }\end{array}$ & Age $65-74$ & Age $>75$ \\
\hline & $(1)$ & $(2)$ & (3) & (4) & (5) & $(6)$ & $(7)$ & (8) \\
\hline Single to MSP Switcher*Post & $\begin{array}{l}-1,168 \\
(823.9)\end{array}$ & $\begin{array}{l}-2,221 \\
(1,699)\end{array}$ & $\begin{array}{l}-2,020 \\
(1,254)\end{array}$ & $\begin{array}{l}-933.5 \\
(1,001)\end{array}$ & & & & \\
\hline MSP to Single Switcher*Post & & & & & $\begin{array}{l}1,272^{*} \\
(728.9)\end{array}$ & $\begin{array}{c}2,494 \\
(1,729)\end{array}$ & $\begin{array}{c}1,591 \\
(1,190)\end{array}$ & $\begin{array}{c}2,043 * * \\
(893.3)\end{array}$ \\
\hline Single to MSP Switcher & $\begin{array}{c}33.94 \\
(418.8)\end{array}$ & $\begin{array}{c}266.9 \\
(806.1)\end{array}$ & $\begin{array}{c}186.7 \\
(579.7)\end{array}$ & $\begin{array}{c}85.74 \\
(520.9)\end{array}$ & & & & \\
\hline MSP to Single Switcher & & & & & $\begin{array}{l}-460.0 \\
(470.3)\end{array}$ & $\begin{array}{l}-25.01 \\
(1,144)\end{array}$ & $\begin{array}{l}-318.5 \\
(740.4)\end{array}$ & $\begin{array}{l}-249.3 \\
(601.9)\end{array}$ \\
\hline Post & $\begin{array}{c}1,369 * * * \\
(260.0) \\
\end{array}$ & $\begin{array}{c}3,472^{* * *} \\
(559.5) \\
\end{array}$ & $\begin{array}{c}1,546^{* * *} \\
(388.4) \\
\end{array}$ & $\begin{array}{c}2,383 * * * \\
(327.2) \\
\end{array}$ & $\begin{array}{c}189.7 \\
(286.3) \\
\end{array}$ & $\begin{array}{r}948.4 \\
(714.4) \\
\end{array}$ & $\begin{array}{l}-446.2 \\
-457.2 \\
\end{array}$ & $\begin{array}{c}834.7 * * \\
-379.2 \\
\end{array}$ \\
\hline HRR and Year Fixed Effects & $\mathrm{N}$ & $\mathrm{N}$ & $\mathrm{N}$ & $\mathrm{N}$ & $\mathrm{N}$ & $\mathrm{N}$ & $\mathrm{N}$ & $\mathrm{N}$ \\
\hline HRR by Year Fixed Effects & $\mathrm{Y}$ & $\mathrm{Y}$ & $\mathrm{Y}$ & $\mathrm{Y}$ & $\mathrm{Y}$ & $\mathrm{Y}$ & $\mathrm{Y}$ & $\mathrm{Y}$ \\
\hline Instumented & $\mathrm{Y}$ & $\mathrm{Y}$ & $\mathrm{Y}$ & $\mathrm{Y}$ & $\mathrm{Y}$ & $\mathrm{Y}$ & $\mathrm{Y}$ & $\mathrm{Y}$ \\
\hline Pre-Move Mean & 3,131 & 6,707 & 4,025 & 4,477 & 3,413 & 7,477 & 4,558 & 4,710 \\
\hline Change $(\%)$ & $-37 \%$ & $-33 \%$ & $-50 \%$ & $-21 \%$ & $37 \%$ & $33 \%$ & $35 \%$ & $43 \%$ \\
\hline No. of patients & 48,245 & 22,724 & 31,398 & 39,373 & 33,693 & 14,610 & 21,444 & 26,613 \\
\hline No. of patient-years & 96,490 & 45,448 & 62,795 & 78,745 & 67,386 & 29,220 & 42,888 & 53,225 \\
\hline
\end{tabular}

Notes: $* * * \mathrm{p}<0.01,{ }^{* *} \mathrm{p}<0.05, * \mathrm{p}<0.1$. All models include controls for chronic conditions, age, sex, race, and year. Standard errors are in parentheses. Construction of sample of movers is described in the text. SSP and MSP represent single and multi-specialty practice. 
Table 8: Estimates of the Effect Primary Care Group Composition on Total Expenditures - Sensitivity Checks

\begin{tabular}{|c|c|c|c|c|c|c|c|c|}
\hline & \multicolumn{8}{|c|}{ Dependent Variable: Total Expenditures } \\
\hline & \multicolumn{2}{|c|}{$\begin{array}{c}\text { Main Estimates (from } \\
\text { Table 3) }\end{array}$} & \multicolumn{2}{|c|}{$\begin{array}{l}\text { Limit to Large MSP } \\
\text { and Small SSP }\end{array}$} & \multicolumn{2}{|c|}{$\begin{array}{c}\text { Low Post-Move MA } \\
\text { Penetration }\end{array}$} & \multicolumn{2}{|c|}{$\begin{array}{c}\text { High Post-Move MA } \\
\text { Penetration }\end{array}$} \\
\hline & $\begin{array}{c}\text { Single SP } \\
\text { before Move } \\
(1)\end{array}$ & $\begin{array}{c}\text { Multi SP } \\
\text { before } \\
\text { Move } \\
(2)\end{array}$ & $\begin{array}{c}\text { Single SP } \\
\text { before } \\
\text { Move } \\
(3)\end{array}$ & $\begin{array}{c}\text { Multi SP } \\
\text { before } \\
\text { Move } \\
(4)\end{array}$ & $\begin{array}{c}\text { Single SP } \\
\text { before } \\
\text { Move } \\
(5)\end{array}$ & $\begin{array}{c}\text { Multi SP } \\
\text { before } \\
\text { Move } \\
(6)\end{array}$ & $\begin{array}{c}\text { Single SP } \\
\text { before } \\
\text { Move } \\
(7)\end{array}$ & $\begin{array}{c}\text { Multi SP } \\
\text { before } \\
\text { Move } \\
(8)\end{array}$ \\
\hline Single to MSP Switcher*Post & $\begin{array}{c}-1,553^{* *} \\
(765.6)\end{array}$ & & $\begin{array}{l}-1,113 \\
(1,195)\end{array}$ & & $\begin{array}{l}-1,720 \\
(1,189)\end{array}$ & & $\begin{array}{l}-1,467 \\
(988.3)\end{array}$ & \\
\hline MSP to Single Switcher*Post & & $\begin{array}{c}1,636^{* *} \\
(704.6)\end{array}$ & & $\begin{array}{c}1,995^{* *} \\
(913.0)\end{array}$ & & $\begin{array}{c}1,727 \\
(1,174)\end{array}$ & & $\begin{array}{c}1,414 \\
(889.3)\end{array}$ \\
\hline Single to MSP Switcher & $\begin{array}{c}50.45 \\
(383.8)\end{array}$ & & $\begin{array}{l}-920.6 \\
(541.9)\end{array}$ & & $\begin{array}{l}-272.9 \\
(576.0)\end{array}$ & & $\begin{array}{c}371.5 \\
(511.9)\end{array}$ & \\
\hline MSP to Single Switcher & & $\begin{array}{l}-326.7 \\
(462.1)\end{array}$ & & $\begin{array}{l}-542.6 \\
(612.4)\end{array}$ & & $\begin{array}{l}-412.8 \\
\end{array}$ & & $\begin{array}{l}-228.6 \\
(649.7)\end{array}$ \\
\hline Post & $\begin{array}{c}2,028^{* * *} \\
(245.3)\end{array}$ & $\begin{array}{r}367.8 \\
(282.7) \\
\end{array}$ & $\begin{array}{c}1,718^{* * *} \\
(285.3)\end{array}$ & $\begin{array}{c}305.6 \\
(271.4) \\
\end{array}$ & $\begin{array}{c}2,119 * * * \\
(378.5)\end{array}$ & $\begin{array}{r}458.2 \\
\quad(478.3) \\
\end{array}$ & $\begin{array}{c}1,958^{* * *} \\
(318.9) \\
\end{array}$ & $\begin{array}{l}360.6 \\
350.8 \\
\end{array}$ \\
\hline HRR and Year Fixed Effects & $\mathrm{N}$ & $\mathrm{N}$ & $\mathrm{N}$ & $\mathrm{N}$ & $\mathrm{N}$ & $\mathrm{N}$ & $\mathrm{N}$ & $\mathrm{N}$ \\
\hline HRR by Year Fixed Effects & $\mathrm{Y}$ & $\mathrm{Y}$ & $\mathrm{Y}$ & $\mathrm{Y}$ & $\mathrm{Y}$ & $\mathrm{Y}$ & $\mathrm{Y}$ & $\mathrm{Y}$ \\
\hline Instrumented & $\mathrm{Y}$ & $\mathrm{Y}$ & $\mathrm{Y}$ & $\mathrm{Y}$ & $\mathrm{Y}$ & $\mathrm{Y}$ & $\mathrm{Y}$ & $\mathrm{Y}$ \\
\hline Pre-Move Mean & 4,514 & 4,774 & 5,502 & 5,613 & 5,374 & 5,727 & 5,399 & 5,635 \\
\hline Change $(\%)$ & $-34 \%$ & $34 \%$ & $-20 \%$ & $36 \%$ & $-32 \%$ & $30 \%$ & $-27 \%$ & $25 \%$ \\
\hline No. of patients & 70,935 & 48,251 & 46,200 & 31,878 & 35,693 & 24,038 & 35,242 & 24,214 \\
\hline No. of patient-years & 141,869 & 96,502 & 92,399 & 63,756 & 71,386 & 48,075 & 92,399 & 63,756 \\
\hline
\end{tabular}

Notes: ${ }^{* * *} \mathrm{p}<0.01,{ }^{* *} \mathrm{p}<0.05,{ }^{*} \mathrm{p}<0.1$. All models include controls for chronic conditions, age, sex, race, and year. Standard errors are in parentheses.

Construction of sample of movers is described in the text. SSP and MSP represent single and multi-specialty practice. Large practice defined as total physicians greater than or equal to 10. Small defined as total physicians less than 10. Low Medicare Advantage (MA) penetration defined as below the median and high defined as above the market-level median. 
Appendix Table 1: First-Stage Estimates for Instrumented Models

\begin{tabular}{|c|c|c|c|c|}
\hline & \multicolumn{2}{|c|}{$\begin{array}{c}\text { Sample: SSP before } \\
\text { Move }\end{array}$} & \multicolumn{2}{|c|}{$\begin{array}{c}\text { Sample: Multi-SP } \\
\text { before Move }\end{array}$} \\
\hline & $\begin{array}{l}\text { Switch } \\
(1)\end{array}$ & $\begin{array}{c}\text { Switch*Post } \\
(2)\end{array}$ & $\begin{array}{l}\text { Switch } \\
(3)\end{array}$ & $\begin{array}{c}\text { Switch*Post } \\
\text { (4) }\end{array}$ \\
\hline Share of MSP in Destination HRR & $\begin{array}{l}0.739 * * * \\
(0.0124)\end{array}$ & $\begin{array}{l}-0.00734 \\
(0.00873)\end{array}$ & & \\
\hline Share of SSP in Destination HRR & & & $\begin{array}{l}0.716^{* * *} \\
(0.0145)\end{array}$ & $\begin{array}{c}-0.00728 \\
(0.0102)\end{array}$ \\
\hline Share of MSP in Destination HRR*Post & $\begin{array}{c}-0.146 * * * \\
(0.0228)\end{array}$ & $\begin{array}{l}0.658 * * * \\
(0.0160)\end{array}$ & & \\
\hline Share of SSP in Destination HRR*Post & & & $\begin{array}{l}-0.0216 \\
(0.0230)\end{array}$ & $\begin{array}{l}0.745^{* * *} \\
(0.0162)\end{array}$ \\
\hline Post & $\begin{array}{l}0.0356^{* * *} \\
(0.00980)\end{array}$ & $\begin{array}{l}0.0351 * * * \\
(0.00689)\end{array}$ & $\begin{array}{c}0.002 \\
(0.0126)\end{array}$ & $\begin{array}{c}-0.012 \\
(0.00890)\end{array}$ \\
\hline F-statistic. H0: Weak Instruments & & 3.38 & & 24.55 \\
\hline R-Squared & 0.069 & 0.257 & 0.08 & 0.313 \\
\hline HRR and Year Fixed Effects & $\mathrm{N}$ & $\mathrm{N}$ & $\mathrm{N}$ & $\mathrm{N}$ \\
\hline HRR by Year Fixed Effects & $\mathrm{Y}$ & $\mathrm{Y}$ & $\mathrm{Y}$ & $\mathrm{Y}$ \\
\hline No. of patients & 70,935 & 70,935 & 48,251 & 48,251 \\
\hline No. of patient-years & 141,869 & 141,869 & 96,502 & 96,502 \\
\hline
\end{tabular}

Notes: ${ }^{* * *} \mathrm{p}<0.01,{ }^{* *} \mathrm{p}<0.05,{ }^{*} \mathrm{p}<0.1$. All models include controls for chronic conditions, age, sex, race, and year. Standard errors are in parentheses. Construction of sample of movers is described in the text. SSP and MSP represent single and multi-specialty practice. 
Appendix Table 2: Effects of Practice Type by Type of Expenditure (HRR and Year Fixed Effects)

\begin{tabular}{|c|c|c|c|c|c|c|}
\hline & \multicolumn{6}{|c|}{ Dependent variable: Type of Expenditures } \\
\hline & \multicolumn{3}{|c|}{ SSP before Move } & \multicolumn{3}{|c|}{ MSP before Move } \\
\hline & $\begin{array}{c}\text { Physician } \\
\text { (1) }\end{array}$ & $\begin{array}{c}\text { Hospital } \\
(2)\end{array}$ & $\begin{array}{c}\text { Outpatient } \\
\text { (3) }\end{array}$ & $\begin{array}{c}\text { Physician } \\
(4)\end{array}$ & $\begin{array}{c}\text { Hospital } \\
(5)\end{array}$ & $\begin{array}{c}\text { Outpatient } \\
(6)\end{array}$ \\
\hline Single to MSP Switcher*Post & $\begin{array}{c}-270.5^{* *} \\
(132.5)\end{array}$ & $\begin{array}{c}-1,298^{* *} \\
(534.5)\end{array}$ & $\begin{array}{l}-40.87 \\
(105.7)\end{array}$ & & & \\
\hline MSP to Single Switcher*Post & & & & $\begin{array}{c}357.3^{* * *} \\
(122.3)\end{array}$ & $\begin{array}{c}1,363 * * \\
(534.8)\end{array}$ & $\begin{array}{l}-82.10 \\
(106.0)\end{array}$ \\
\hline Single to MSP Switcher & $\begin{array}{c}96.74 \\
(77.94)\end{array}$ & $\begin{array}{l}-136.8 \\
(314.5)\end{array}$ & $\begin{array}{c}58.35 \\
(62.19)\end{array}$ & & & \\
\hline MSP to Single Switcher & & & & $\begin{array}{l}-77.19 \\
(87.54)\end{array}$ & $\begin{array}{l}-449.0 \\
(382.7)\end{array}$ & $\begin{array}{c}84.39 \\
(75.82)\end{array}$ \\
\hline Post & $\begin{array}{c}412.9^{* * *} \\
(43.89) \\
\end{array}$ & $\begin{array}{c}1,497 * * * \\
(177.1)\end{array}$ & $\begin{array}{c}118.0^{* * *} \\
(35.02)\end{array}$ & $\begin{array}{c}72.13 \\
(49.69) \\
\end{array}$ & $\begin{array}{c}181.9 \\
(217.2) \\
\end{array}$ & $\begin{array}{c}104.0^{* *} \\
(43.04)\end{array}$ \\
\hline HRR and Year Fixed Effects & Y & Y & $\mathrm{Y}$ & Y & Y & Y \\
\hline HRR by Year Fixed Effects & $\mathrm{N}$ & $\mathrm{N}$ & $\mathrm{N}$ & $\mathrm{N}$ & $\mathrm{N}$ & $\mathrm{N}$ \\
\hline Instrumented & Y & Y & Y & $\mathrm{Y}$ & Y & $\mathrm{Y}$ \\
\hline Pre-Move Mean & 1,717 & 2,414 & 382 & 1,670 & 2,727 & 377 \\
\hline Change $(\%)$ & $-16 \%$ & $-54 \%$ & $-11 \%$ & $21 \%$ & $50 \%$ & $-22 \%$ \\
\hline No. of patients & 70969 & 70969 & 70969 & 48303 & 48303 & 48303 \\
\hline No. of patient-years & 141,938 & 141,938 & 141,938 & 96,606 & 96,606 & 96,606 \\
\hline
\end{tabular}


Appendix Table 3: Effects of Practice Type on Hospitalizations (HRR and Year Fixed Effects)

\begin{tabular}{|c|c|c|c|c|}
\hline & \multicolumn{4}{|c|}{ Dependent variable: Hospitalizations } \\
\hline & \multicolumn{2}{|c|}{ SSP before Move } & \multicolumn{2}{|c|}{ MSP before Move } \\
\hline & $\begin{array}{c}1 \text { or More } \\
\text { Hosp } \\
(1)\end{array}$ & $\begin{array}{c}2 \text { or More } \\
\text { Hosp } \\
(2)\end{array}$ & $\begin{array}{c}1 \text { or More } \\
\text { Hosp } \\
\text { (3) }\end{array}$ & $\begin{array}{c}2 \text { or More } \\
\text { Hosp } \\
(4)\end{array}$ \\
\hline Single to MSP Switcher*Post & $\begin{array}{l}-0.0228 \\
(0.0249)\end{array}$ & $\begin{array}{l}-0.0211 \\
(0.0168)\end{array}$ & & \\
\hline MSP to Single Switcher*Post & & & $\boldsymbol{F} \begin{array}{c}0.0474 * * \\
(0.0241)\end{array}$ & $-\begin{array}{c}0.0505^{* * *} \\
(0.0162)\end{array}$ \\
\hline Single to MSP Switcher & $\begin{array}{cc}\boldsymbol{V} & 0.0128 \\
& (0.0146)\end{array}$ & $\begin{array}{l}-0.00111 \\
(0.00987)\end{array}$ & & \\
\hline MSP to Single Switcher & & & $\boldsymbol{F} \begin{array}{l}-0.0303^{*} \\
(0.0172)\end{array}$ & $\begin{array}{l}-0.0171 \\
(0.0116)\end{array}$ \\
\hline Post & $\nabla \begin{array}{c}0.0633^{* * *} \\
(0.00824)\end{array}$ & $\begin{array}{c}0.0453^{* * *} \\
(0.00556)\end{array}$ & $\boldsymbol{V} \begin{array}{l}0.0208 * * \\
(0.00978)\end{array}$ & $\begin{array}{c}0.00831 \\
(0.00658) \\
\end{array}$ \\
\hline HRR and Year Fixed Effects & $\mathrm{Y}$ & $\mathrm{Y}$ & $\mathrm{Y}$ & $\mathrm{Y}$ \\
\hline HRR by Year Fixed Effects & $\mathrm{N}$ & $\mathrm{N}$ & $\mathrm{N}$ & $\mathrm{N}$ \\
\hline Instrumented & $\mathrm{Y}$ & $\mathrm{Y}$ & $\mathrm{Y}$ & $\mathrm{Y}$ \\
\hline Pre-Move Mean & 0.21 & 0.07 & 0.23 & 0.07 \\
\hline Change $(\%)$ & $-11 \%$ & $-32 \%$ & $21 \%$ & $68 \%$ \\
\hline No. of patients & 70,969 & 70,969 & 48,303 & 48,303 \\
\hline No. of patient-years & 141,938 & 141,938 & 96,606 & 96,606 \\
\hline
\end{tabular}


Appendix Table 4: Effects of Practice Type on Expenditures by Chronic Conditions and Age (HRR and Year Fixed Effects)

\begin{tabular}{|c|c|c|c|c|c|c|c|c|}
\hline & \multicolumn{8}{|c|}{ Dependent variable: Total Expenditures } \\
\hline & \multicolumn{4}{|c|}{ Single SP before Move } & \multicolumn{4}{|c|}{ Multi SP before Move } \\
\hline & $\begin{array}{l}\text { 0-2 Chronic } \\
\text { Conditions }\end{array}$ & $\begin{array}{c}>2 \\
\text { Chronic } \\
\text { Conditions }\end{array}$ & Age 65-74 & Age $>75$ & $\begin{array}{c}\text { 0-2 } \\
\text { Chronic } \\
\text { Conditions }\end{array}$ & $\begin{array}{c}>2 \\
\text { Chronic } \\
\text { Conditions }\end{array}$ & Age $65-74$ & Age $>75$ \\
\hline & $(1)$ & $(2)$ & (3) & (4) & $(5)$ & $(6)$ & $(7)$ & $(8)$ \\
\hline Single to MSP Switcher*Post & $\begin{array}{l}-1,100 \\
(678.3)\end{array}$ & $\begin{array}{l}-2,334 * \\
(1,382)\end{array}$ & $\begin{array}{l}-1,946^{*} \\
(1,005)\end{array}$ & $\begin{array}{l}-1,375 \\
(845.0)\end{array}$ & & & & \\
\hline MSP to Single Switcher*Post & & & & & $\begin{array}{l}994.1 \\
-639.8\end{array}$ & $\begin{array}{l}2,592^{*} \\
(1,526)\end{array}$ & $\begin{array}{c}1,632 \\
(1,058)\end{array}$ & $\begin{array}{c}1,675^{* *} \\
(787.2)\end{array}$ \\
\hline Single to MSP Switcher & $\begin{array}{c}20.43 \\
(408.4)\end{array}$ & $\begin{array}{c}144.1 \\
(769.2)\end{array}$ & $\begin{array}{c}160.3 \\
(565.9)\end{array}$ & $\begin{array}{l}-27.26 \\
(504.7)\end{array}$ & $\begin{array}{l}-497.5 \\
(456.4)\end{array}$ & $\begin{array}{l}-483.4 \\
(1,084)\end{array}$ & & \\
\hline MSP to Single Switcher & & & & & & & $\begin{array}{l}-540.1 \\
(710.0)\end{array}$ & $\begin{array}{l}-292.7 \\
(584.2)\end{array}$ \\
\hline Post & $\begin{array}{c}1,298^{* * * *} \\
(222.4) \\
\end{array}$ & $\begin{array}{c}3,549 * * * \\
(471.7) \\
\end{array}$ & $\begin{array}{c}1,461 * * * \\
(324.4) \\
\end{array}$ & $\begin{array}{c}2,499 * * * \\
(285.5) \\
\end{array}$ & $\begin{array}{c}270.2 \\
(255.4) \\
\end{array}$ & $\begin{array}{r}870.4 \\
(636.3) \\
\end{array}$ & $\begin{array}{l}-446.0 \\
(410.0) \\
\end{array}$ & $\begin{array}{c}978.9 * * * \\
(331.7) \\
\end{array}$ \\
\hline HRR and Year Fixed Effects & $\mathrm{Y}$ & $\mathrm{Y}$ & $\mathrm{Y}$ & $\mathrm{Y}$ & $\mathrm{Y}$ & $\mathrm{Y}$ & $\mathrm{Y}$ & Y \\
\hline HRR by Year Fixed Effects & $\mathrm{N}$ & $\mathrm{N}$ & $\mathrm{N}$ & $\mathrm{N}$ & $\mathrm{N}$ & $\mathrm{N}$ & $\mathrm{N}$ & $\mathrm{N}$ \\
\hline Instumented & $\mathrm{Y}$ & Y & Y & Y & $\mathrm{Y}$ & $\mathrm{Y}$ & $\mathrm{Y}$ & Y \\
\hline Pre-Move Mean & 3,131 & 6,707 & 4,025 & 4,477 & 3,413 & 7,477 & 4,558 & 4,710 \\
\hline Change $(\%)$ & $-35 \%$ & $-35 \%$ & $-48 \%$ & $-31 \%$ & $29 \%$ & $35 \%$ & $36 \%$ & $36 \%$ \\
\hline No. of patients & 48,245 & 22,724 & 31,516 & 39,454 & 33,693 & 14,610 & 21,588 & 26,716 \\
\hline No. of patient-years & 96,490 & 45,448 & 63,031 & 78,907 & 67,386 & 29,220 & 43,175 & 53,431 \\
\hline
\end{tabular}

